\title{
TERRITORIALIDADE E ARRANJOS INSTITUCIONAIS DA ECONOMIA SOLIDÁRIA NO MEIO RURAL POTIGUAR ${ }^{1}$
}

\author{
Leandro de Castro Lima ${ }^{2}$ \\ Celso Donizete Locatel ${ }^{3}$
}

\section{Resumo}

A Economia Solidária promove novas formas de organização da produção e de relações sociais, que ao se realizar possibilita diferentes usos do território, se constituindo enquanto uma alternativa orgânica às relações de trabalho capitalista estabelecidas no meio rural. Entretanto, ao ser implementada como Política Pública, possibilitou o surgimento de arranjos institucionais que revelam formas complexas e contraditórias de usos do território, ocasionada pela racionalidade normativa hegemônica do Estado. Nesse sentido, buscamos identificar nesse artigo os impactos e limitações na reprodução dos empreendimentos solidários rurais do Rio Grande do Norte, evidenciado em que medida essa política contribuiu para as mudanças organizacionais internas aos empreendimentos solidários e no fortalecimento do uso do território potiguar, enquanto abrigo, com maior inserção no mercado e garantia de direitos sociais.

Palavras-Chaves: Uso do território, Economia Solidária, Arranjo Institucional, Rio Grande do Norte.

\section{TERRITORIALITY AND INSTITUTIONAL ARRANGEMENTS OF THE SOLIDARITY ECONOMY IN RURAL POTIGUAR}

\begin{abstract}
The Solidarity Economy promotes new forms of organization of production and social relations, which, when carried out, enable different uses of the territory, constituting an organic alternative to capitalist labor relations established in rural areas. However, when implemented as a Public Policy, it enabled the emergence of institutional arrangements that reveal complex and contradictory forms of land use, caused by the hegemonic normative rationality of the State. In this sense, we seek to identify in this article the impacts and limitations on the reproduction of rural solidarity projects in Rio Grande do Norte, showing the extent to which this policy contributed to organizational changes within the solidarity projects and in strengthening the use of the Potiguar territory, as a hideaway, with greater insertion in the market and guarantee of social rights.
\end{abstract}

Keywords: Use of territory, Solidarity Economy, Institutional Arrangement, Rio Grande do Norte.

\footnotetext{
${ }^{1}$ Este artigo é parte da dissertação "Os usos do território e a economia solidária no Rio Grande do Norte", apresentada ao Programa de Pós-graduação e Pesquisa em Geografia (PPGeo) da UFRN sob a orientação do Prof. Dr. Celso Locatel.

${ }^{2}$ Doutor em Geografia pela UFRN. Professor do Ensino Básico, Técnico e Tecnológico do Instituto Federal do Ceará, campus Iguatu. E-mail: leandro.lima@ifce.edu.br

${ }^{3}$ Doutor em Geografia pela UNESP/PP. Professor Associado da Universidade Federal do Rio Grande do Norte. Email: celso.locatel@ufrn.br
} 


\section{TERRITORIALIDAD Y ARREGLOS INSTITUCIONALES DE LA ECONOMÍA SOLIDARIA EN POTIGUAR RURAL}

\section{Resumen}

La Economía Solidaria promueve nuevas formas de organización de la producción y las relaciones sociales que, cuando se llevan a cabo, posibilitan diferentes usos del territorio, constituyendo una alternativa orgánica a las relaciones laborales capitalistas establecidas en el medio rural. Sin embargo, cuando se implementó como Política Pública, permitió el surgimiento de arreglos institucionales que revelan formas complejas y contradictorias de uso del suelo, provocadas por la racionalidad normativa hegemónica del Estado. En este sentido, buscamos identificar en este artículo los impactos y limitaciones en la reproducción de proyectos de solidaridad rural en Rio Grande do Norte, mostrando en qué medida esta política contribuyó a cambios organizacionales dentro de los proyectos solidarios y en el fortalecimiento del uso de la Territorio Potiguar, como refugio, con mayor inserción en el mercado y garantía de derechos sociales.

Palabras clave: Uso del territorio, Economía Solidaria, Arreglo Institucional, Rio Grande do Norte.

\section{INTRODUÇÃO}

O uso agrícola do território no Rio Grande do Norte a partir da difusão do movimento cooperativista, intensificado na década de 1980, foi implementada como alternativa à crise das atividades tradicionais, motivada pelas profundas desigualdades socioeconômicas ocasionadas pelos sistemas técnicos implementados e pelo processo de modernização agrícola das novas atividades que surgiam. Em meio à crise, a mobilização e organização dos trabalhadores, em sua maioria subjugados a precárias relações de trabalho, nas agroindústrias ou nos latifúndios, chamou atenção de algumas organizações, como o Estado e a Igreja Católica, que passaram a facilitar o acesso ao crédito e as formas de organização sociais, respectivamente, para a superação das precárias condições econômica vivida por estes trabalhadores.

Percebemos, dentro dessa realidade, que o território vai apresentando distintos uso, inicialmente como abrigo, realizada pelos sujeitos subjugados, ao implementar, por exemplo, formas associativas de produção como alternativa as más condições de trabalho e desigualdade sociais coletivas e, posteriormente, como recurso a partir das normatizações e regulações do território sob estas associações agrícolas, ocasionada pelas ações verticais do Estado, enquanto sujeito hegemônico, propiciando a organização e a sujeição destas novamente as empresas e as agroindústrias, visando a simples manutenção das práticas capitalista, agora dentro do ideário 
associativista que, a partir de 2003, é incorporada na formação de política de governo, considerando os princípios da Economia Solidária.

Enquanto Política Pública, a Economia Solidária apresenta disparidade na sua execução que leva, de acordo com Santos (2000, p. 285), “a incorporação de nexos e normas externas que têm um efeito desintegrador das solidariedades locais então vigentes, com a perda correlativa da capacidade de gestão da vida local". Nesse sentido, para uma compreensão do fenômeno da economia Solidária a partir do território, ressaltamos os seus diferentes usos, pois segundo Santos e Silveira (2008), somente a partir dos usos do território compreendemos as transformações sociais e produtivas que nele ocorre. Assim, invertemos nossa perspectiva, e partimos da análise dos empreendimentos solidários em toda a sua organicidade, relações de trabalho, produtiva e condições socioeconômicas, para compreendemos suas relações políticas, a partir dos impactos ocasionados pela regulação e normatização realizadas pelo Estado.

Desta forma, neste trabalho, buscamos identificar os efeitos da Política Nacional de Economia Solidária no território do Rio Grande do Norte, bem como os seus impactos na reprodução dos empreendimentos solidários, questionando até que ponto essa política tem contribuído nas mudanças organizacionais dos empreendimentos e fortalecendo o uso do território enquanto abrigo. Essa perspectiva se coloca, pois, a Política de Economia Solidária no Rio Grande do Norte, teve rebatimentos nas mais diversas porções do território potiguar, revelando particularidades e desafios, em meio a forte resistência, ainda encontrada, devido ao predomínio de uma cultura individualista e de extrema exploração, em detrimento de uma cultura coletiva, solidária e participativa.

Para além do discurso e da racionalidade dominante, em termos metodológicos, além do levantamento bibliográfico sobre o fenômeno da economia solidária e a dimensão territorial, também realizamos o levantamento de dados sobre os empreendimentos rurais de economia solidária, no banco de dados da Secretaria Nacional de Economia Solidária (SENAES, 2013), por meio do Sistema Nacional de Informações em Economia Solidária (SIES, 2015). Após sistematizados, os dados possibilitaram a organização de gráficos, os quais nos permitiram caracterizar as mudanças organizacionais e das condições socioeconômicas, dos principais beneficiários da política.

Ainda acrescentamos a discussão, algumas das nossas observações in lócus, com o intuito de contrastarmos com os dados secundários apresentados e refletindo sobre o real contexto das relações de trabalho e produção, da utilização dos princípios solidários e dos níveis 
de satisfação dos trabalhadores solidários envolvidos, na tentativa de compreender os desafios e dificuldades enfrentados por estes.

Este capítulo está estruturado em duas partes, além desta introdução e das considerações finais. Na primeira parte é apresentado a realidade institucional da Economia Solidária potiguar, destacando a diversidade das ações e agentes que atuam na operacionalização da política pública, e, posteriormente, na segunda parte é apresentado a dimensão organizacional dos empreendimentos solidários, a fim de compreendermos as complexas relações da produção associada, muitas vezes negligenciadas pela atuação contraditória do Estado, bem como dos limites e possibilidades desses empreendimentos a partir da realidade norte-rio-grandense.

\section{A ECONOMIA SOLIDÁRIA POTIGUAR E SEUS ARRANJOS INSTITUCIONAIS}

No Rio Grande do Norte, a expansão da Economia Solidária se gesta no final da década de 1990, ainda um pouco anterior ao seu período de institucionalização enquanto Política Pública, acompanhando a atuação de alguns movimentos sociais de base popular articulados ao Estado e ações associativistas autônomas, a partir de camponeses que buscavam melhores condições de produção e comercialização. É somente na década de 2000 que a Economia Solidária começa a se efetivar mais expressivamente no território do RN, enquanto Política Pública a partir do ano de 2003, com a criação de Secretaria Nacional de Economia Solidária (SENAES) no governo Lula.

Com a institucionalização da Política de Economia Solidária, a expressividade dos empreendimentos solidários passa a ser reconhecida em todo o país. De acordo com pesquisa realizada pela SENAES (2013), só no Rio Grande do Norte em 2013 foram 1.600 empreendimentos de economia solidária, distribuído no território do Rio Grande do Norte. Do número total de empreendimentos solidários, 1.104 são estruturados a partir de atividades rurais, conforme se observa no Mapa 1.

No mapa apresentado, percebemos a materialidade da Economia Solidária presente em quase todo estado, com destaque para os municípios de Mossoró, Baraúnas, Governador DixSept Rosado e Apodi, na região do Alto Oeste, que apresenta uma territorialidade associativa rural historicamente favorável para a reprodução social dos agricultores associados, concentrando o maior número de empreendimentos solidários nas atividades da agricultura e da pecuária (SENAES, 2013). 
De modo geral, esses empreendimentos solidários são responsáveis por grande parte da produção norte-rio-grandense, se destacando na agricultura, apicultura, ovinocultura, piscicultura e caprinocultura, voltados para abastecer o mercado interno, principalmente nas feiras livres e nos mercados institucionais. Embora no contexto das desigualdades socioespaciais, há no meio rural um isolamento desses empreendimentos solidários em relação aos lugares de comercialização, elemento que ainda se configura como um desafio central no âmbito da Economia Solidária, ou seja, o acesso aos mercados.

Mapa 1. Rio Grande do Norte: número de Empreendimentos Solidários Rurais por Município, 2013

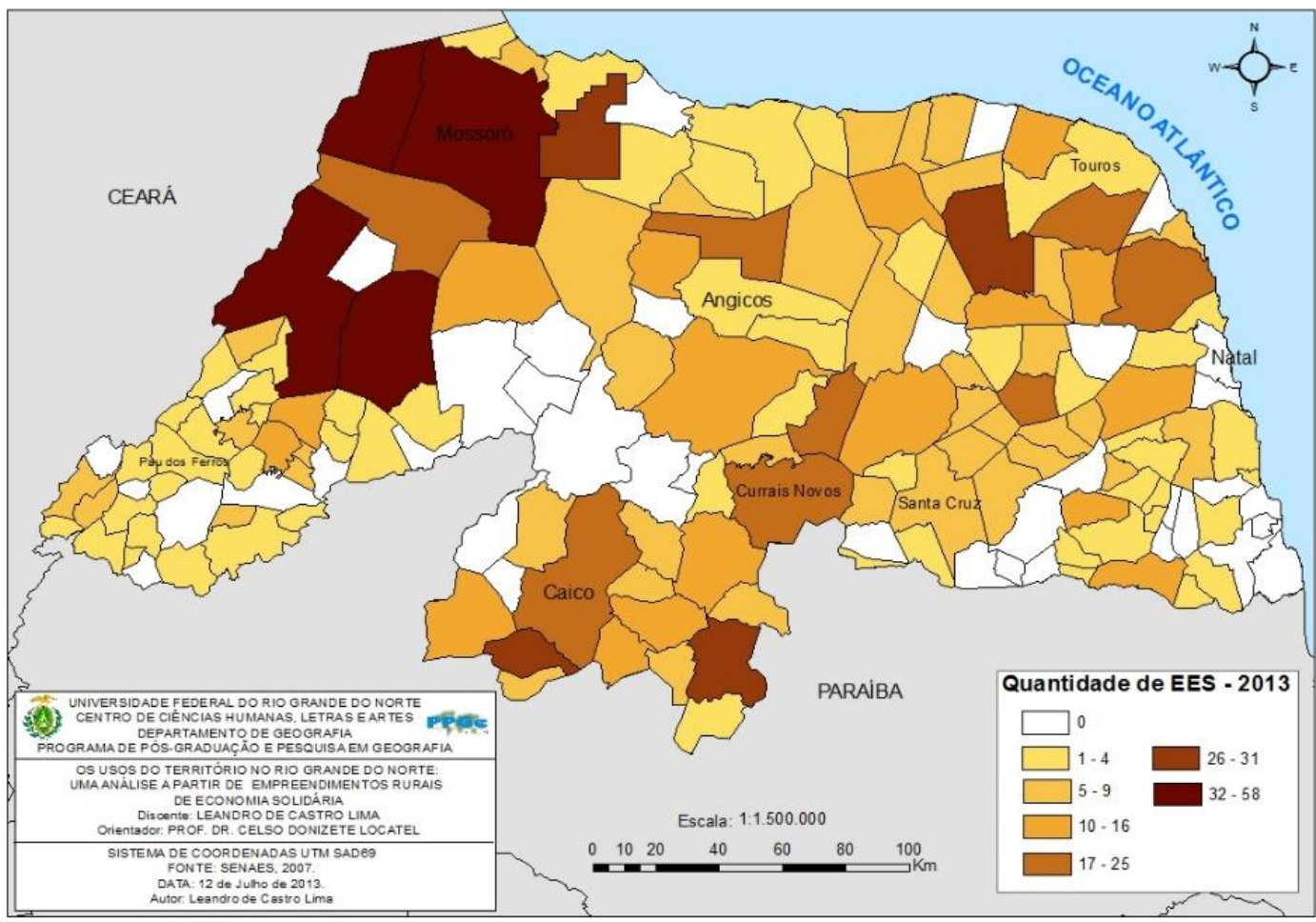

Fonte: SENAES, 2013.

Essa dimensão material da Economia Solidária potiguar, marca uma territorialidade que reforça um processo de reorganização no uso agrícola do território, dada a diversidade produtiva, que envolve diferentes agricultores associados com os mesmos princípios e valores de organização. Muitos dos empreendimentos solidários do RN se articulam em circuitos produtivos, formando uma rede que reaproxima a produção, do beneficiamento e da comercialização, fazendo com que o agricultor dinamize sua produção e tenha uma relação mais estreita com o mercado convencional, ou seja, diretamente com o consumidor final, quebrando a presença de algum atravessador, que do seu trabalho o expropria. 
Todavia, as constatações das mudanças nas organizações associativas no estado não foram apenas no quantitativo da materialidade territorial, foi também no qualitativo, pois os empreendimentos solidários sob o princípio da autogestão devolveram aos agricultores familiares o processo de tomada de decisão das diferentes dimensões, como produção, comercialização, créditos, sobras, bem como todo planejamento, incorporando assim novas funcionalidades, sobretudo na articulação política estadual. Tal expressividade e luta política, demonstrado nos dados do último mapeamento executado pela SENAES (2013) que, no Rio Grande do Norte foi realizado pela Universidade Federal do Rio Grande do Norte (UFRN), ganhou força em 2011, com a criação de um programa específico pelo governo estadual.

Sendo assim, foi no governo da Rosalba Ciarlini (2011-2014) que, por intermédio das classes populares e das lideranças políticas progressistas, foi criado o programa "Desenvolvimento Solidário", no âmbito da Secretaria de Trabalho, Habitação e Assistência Social (SETHAS), tendo por objetivo fomentar ações econômicas solidárias no estado, em todas as suas dimensões, seja no tocante aos investimentos, a produção, as feiras de comercialização ou a realizações de discussões e eventos, estruturadas a partir da implementação de projetos solidários.

Ressaltando a importância dessas entidades, destacamos no Rio Grande do Norte a UFRN, a UERN e a UFERSA. Todas essas universidades através dos seus programas de extensão vêm possibilitando a produção de conhecimento sobre a Economia Solidária, com estudos, pesquisas e publicações de materiais didáticos pedagógicos, bem como a constituição de um banco de dados sobre os empreendimentos solidários, no qual fomentaram o mapeamento da SENAES (2013), a formação acadêmica de lideranças dos empreendimentos e a incorporação de tecnologias sociais aos Empreendimentos de Economia Solidária.

Outro ponto importante é a incorporação de Tecnologias Sociais, que apesar de não ser o foco da nossa discussão, a implantação destas tecnologias, principalmente para a convivência com o semiárido, ganha importância entre os empreendimentos solidários, com a atuação da Articulação no Semiárido Brasileiro (ASA), que também propõe técnicas de preservação ambiental, inclusive para o solo, nas áreas mais degradas do semiárido. Nesse contexto, a EMATER, responsável pelas ações de assistência técnica, passa a atua no Programa de Desenvolvimento Solidário, apesar de já ser responsável pela assistência técnica em todo o estado, inclusive para as associações e cooperativas.

Contudo, a inserção da EMATER no programa proporcionou alguns investimentos em termos de infraestrutura, a fim de melhorar o atendimento a esses empreendimentos, embora 
ainda haja uma escassez da sua atuação, principalmente pela falta de recursos humanos. $\mathrm{O}$ organograma apresentado na Figura 1 ilustra bem a atuação da SETHAS e toda a sua articulação com os diferentes agentes sociais, de forma direta ou indireta, para a atender os empreendimentos solidários do estado.

Figura 1. A estrutura organizacional da Economia Solidária Potiguar

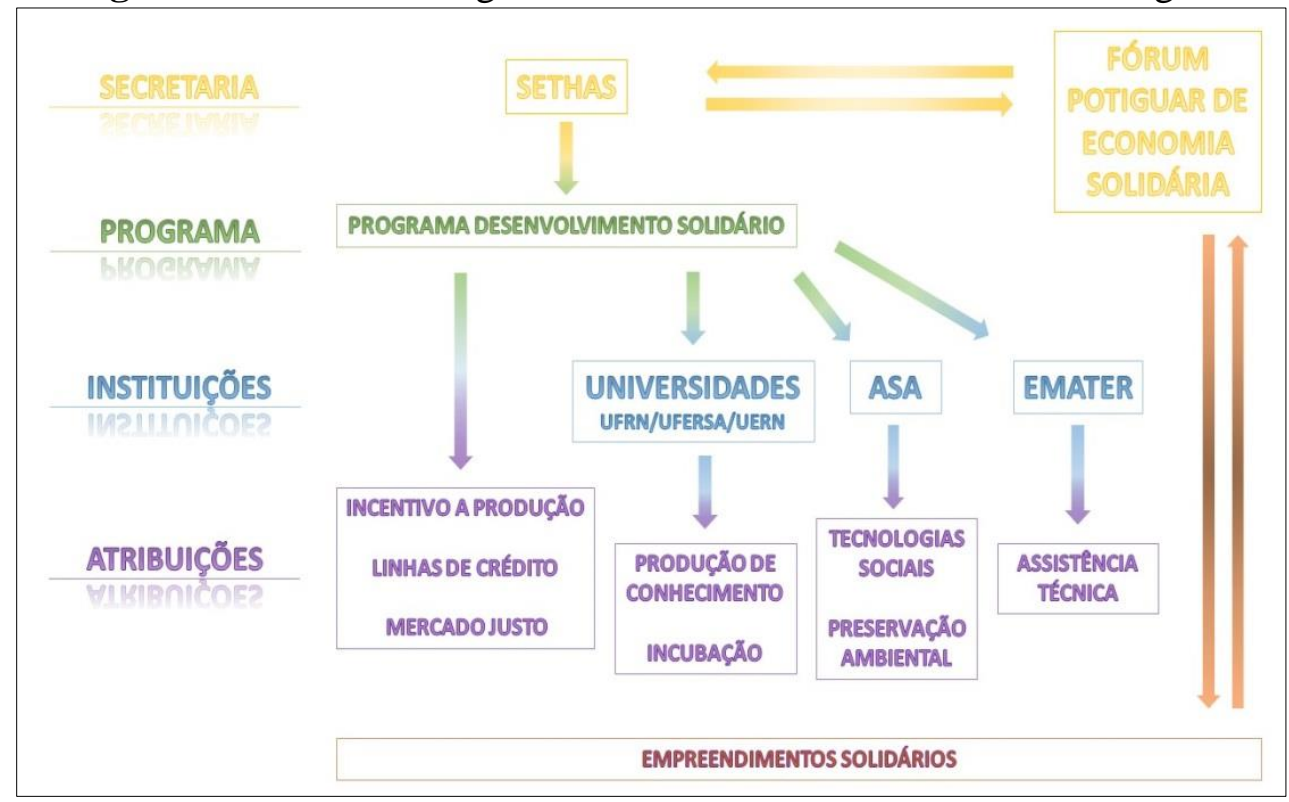

Fonte: Elaboração Própria, 2014.

O organograma evidencia a posição e as atribuições que cada instituição tem associado a SETHAS, através do Programa Desenvolvimento Solidário. Cabe destacar nesse processo, a atuação do Fórum Potiguar de Economia Solidária, responsável por articular as discussões dos associados, através da realização de oficinas, reuniões e encontros, para propor medidas autoorganizativas, bem como levar ações propositivas para a boa atuação da secretaria, nas suas atribuições de executar a Política Nacional de Economia Solidária no estado. A seta dupla, representa a relação de feedback que o fórum vem obtendo no diálogo com os empreendimentos solidários e a secretaria.

Entre as atribuições proposta do fórum ao secretário, destaca-se de maneira geral o fortalecimento político dos empreendimentos solidários e a ampliação do alcance territorial da política pública, a fim de fortalecer a organização dos empreendimentos solidários em redes e circuitos, articulando a produção, distribuição, comercialização, consumo e finanças solidárias, em toda sua diversidade, investimentos, associações com outros programas e autonomia em suas ações democráticas. 
Nessa conjuntura é importante frisar que o organograma concebido não é um modelo rígido, tampouco único. Vários outros agentes sociais se somam ao Programa Desenvolvimento Solidário que, inclusive, contribui também para os empreendimentos urbanos e grupos tradicionais da agricultura familiar, pesca e artesanato. A estrutura colocada demonstra, de forma clara, a atuação e interação dos principais agentes envolvidos nos empreendimentos rurais do $\mathrm{RN}$ e da realidade que encontramos no momento do campo deste trabalho, para as quais as formas de atuação de cada agente foram efetivamente percebidas.

A efetivação desse arranjo normativo e institucional, na esfera estadual, perpassada por diferentes agentes e dimensões organizacionais, garantiu, mesmo diante da fragilidade da Economia Solidária enquanto política pública ${ }^{4}$, uma segurança normativa para a continuidade das ações e o atendimento das demandas específicas dos associados. Assim, mesmo com a extinção do Ministério do Trabalho e Emprego (MTE) e a transferência da SENAES para o Ministério da Cidadania, ocasionando o corte orçamentário para apoio às iniciativas de economia solidária, e a sua restrição à política de assistência social e renda, a partir de 2019, com o governo Bolsonaro (2019-2022), o Governo Estadual, via o recurso normativo de decreto $^{5}$, manteve essa política no âmbito do Rio Grande do Norte, com a criação do Plano Estadual de Economia Solidária.

O Decreto assinado pela governadora Fátima Bezerra em 2021, regulamenta a Lei ${ }^{\circ}$ 8.798, de 2006, no qual instituiu a Política Estadual de Fomento à Economia Popular Solidária e constituiu o Conselho Estadual de Economia Popular e Solidária (CEEPS). Diante dessas medidas estaduais, o movimento da economia solidária ganha uma maior complexidade e se capilariza na política do estado, consolidando uma base normativa legal que amplia a articulação e o apoio aos empreendimentos solidários, fortalece a sua territorialidade, além de viabilizar a comercialização coletiva dos agricultores e a reprodução social destes.

Nesse sentido, buscamos evidenciar, na próxima seção, as mudanças organizacionais nas condições socioeconômicas dos empreendimentos solidários no $\mathrm{RN}$, a partir de um comparativo entre os dados secundários da SENAES (2013) e os dados primários coletados em campo, durante nossa pesquisa de mestrado, a fim de constituirmos a real situação desses empreendimentos e compreendermos como o Estado vem atuando nessa realidade.

4 Essa fragilidade institucional da Política de Economia Solidária é analisada de forma aprofundada em: LOCATEL, C. D.; LIMA, L. C.. Do cooperativismo à economia solidária no Brasil: normatização e dinâmica econômica no campo. In: ZAAR, Miriam; CAPEL, Horacio. (Org.). Las Ciencias Sociales y la Edificación de una Sociedad Post-Capitalista. 1ed.Barcelona: Universidad de Barcelona/Geocrítica, 2018, v. 1, p. 1-22.

${ }^{5}$ Decreto $\mathrm{N}^{\circ} 30.371$, de 02 de fevereiro de 2021, que dispõe sobre o Programa Estadual de Crédito da Economia Solidária (CREDSOLIDÁRIO/RN) e dá outras providências. 


\section{O CONTEXTO ORGANIZACIONAL E SOCIOECONÔMICO DOS EMPREENDIMENTOS SOLIDÁRIOS NO MEIO RURAL POTIGUAR: RUPTURAS E PERMANÊNCIAS}

Na realidade diversa e contraditória dos usos do território, sob a égide do modo de produção capitalista, toda materialidade implementada não se constituí sem intencionalidades. Ao implementar a Economia Solidária como política pública, o Estado não tem a neutralidade, uma vez que sua atuação não se desvencilha das forças hegemônicas. Nesse sentido, as ações planificadoras do Estado, de cunho mais social, surgiram permeadas pelo conteúdo ideológico, para atenderem certas demandas sociais, no intuito de atingirem determinados objetivos, embora sejam de forma parcial, como na Economia Solidária Potiguar, cujas limitações têm relação direta com a realidade nacional.

A partir dos dados obtidos pelo Mapeamento da Economia Solidária no Rio Grande do Norte, realizado em 2013, disponível no SIES (2015), a Economia Solidária está presente em 132 municípios, do total de 167, representando 79,04\% dos municípios norte-rio-grandense, apesar de muitas vezes ser apenas 1 ou 2 empreendimentos em cada município. Por outro lado, em termos populacionais, verifica-se que $3,12 \%$ da população do RN estão vinculados de alguma forma à Economia Solidária, que em termos absolutos representam 106.523 pessoas envolvidas, num universo de 3.408.510 de habitantes, tal como indica a Tabela 1.

Tabela 1. Rio Grande do Norte: representação dos participantes da Economia Solidária em relação ao número de população

\begin{tabular}{c|c|c|c|c}
\hline \multirow{2}{*}{ Variável } & \multirow{2}{*}{$\mathrm{N}^{\circ}$ Total } & \multirow{2}{*}{ Porcentagem } & \multicolumn{2}{|c}{ Dados do Mapeamento no RN } \\
& & & $\mathrm{N}^{\circ}$ Total & Porcentagem \\
\hline População Total do RN & 3.408 .510 & $100 \%$ & 106.523 & $3,12 \%$ \\
\hline $\mathrm{N}^{\circ}$ de Municípios & 167 & $100 \%$ & 132 & $79,04 \%$ \\
\hline
\end{tabular}

Fonte: IBGE, 2014; SIES, 2013.

Com enfoque para esse universo dos associados, a pesquisa da SENAES elencou 14 motivos que levaram os associados a criarem o empreendimento, dos quais cada empreendimento poderia destacar 3 motivos em ordem de importância. Assim, acompanhando o contexto nacional, no Rio Grande do Norte, os dados institucionais apresentam três principais motivos em destaque: alternativa ao desemprego (35,83\%); obtenção de maiores ganhos em um empreendimento associativo (35,31\%); e desenvolvimento comunitário das capacidades e 
potencialidades $(34,71 \%)$. Na metodologia proposta pela pesquisa, auferimos que, apesar das diferentes porcentagens, esses três motivos apresentam o mesmo grau de importância.

Outros motivos, não menos importante, também foram apontados pelos empreendimentos solidários, os quais buscam na Economia Solidária, seja uma fonte complementar de renda $(30,39 \%)$, condições para acesso de financiamento $(25,30 \%)$, incentivo dado pelo estado $(17,09 \%)$, uma motivação social $(10,79 \%)$ e até mesmo para comercializar a produção orgânica $(4,14 \%)$, conforme dados representados no Gráfico 1.

Gráfico 1. Rio Grande do Norte:

motivo de criação do Empreendimento Solidário (2013)

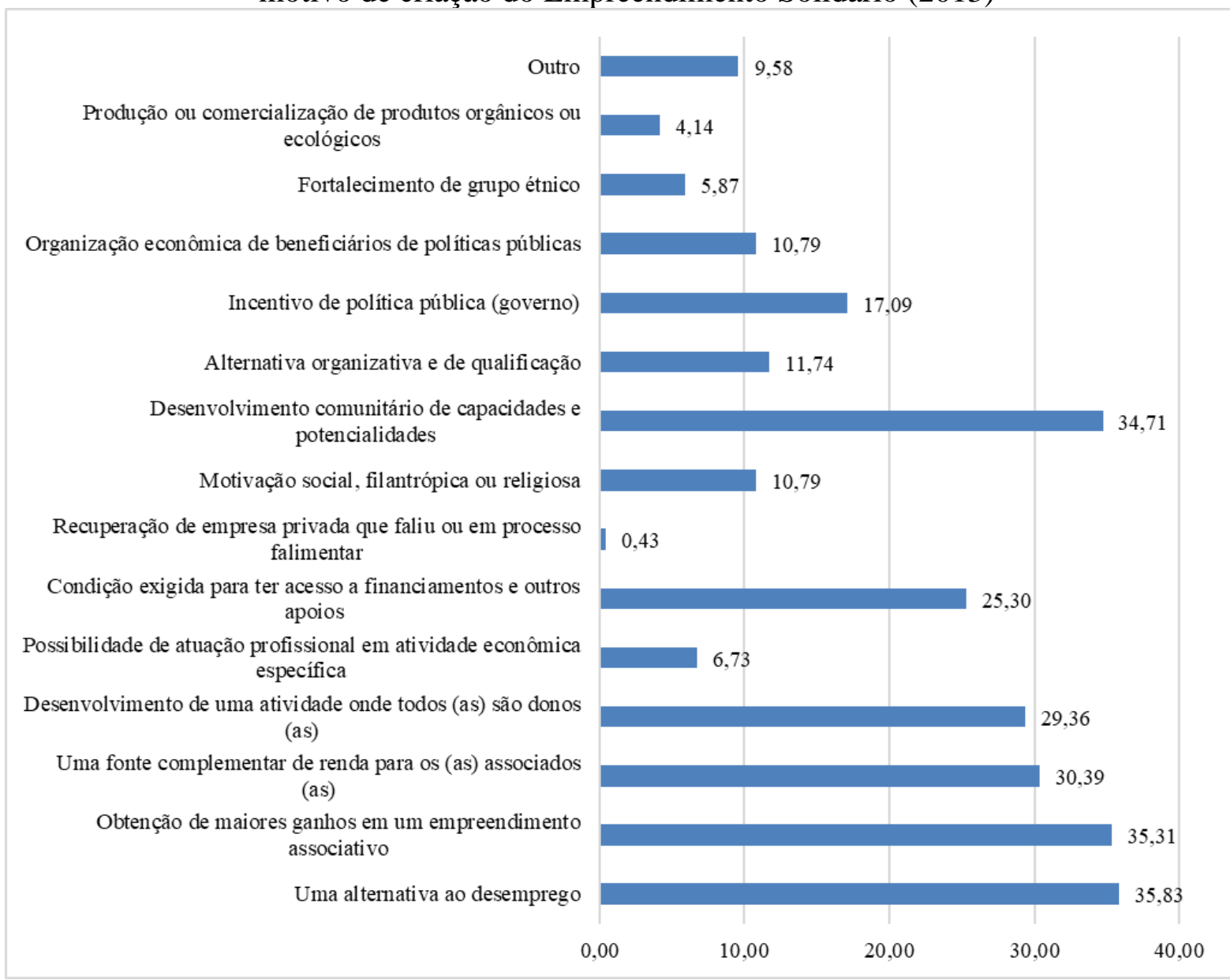

Fonte: SIES, 2013.

O conjunto de motivos que levaram à criação dos empreendimentos solidários no RN, relaciona-se as precárias relações de trabalho gestadas no território potiguar, sobretudo na área rural, onde as ações do estado e a modernização agrícola expropriavam os pequenos agricultores, que tinham na Economia Solidária uma alternativa para essa realidade, embora existam alguns fatores de motivação ideológica. 
$\mathrm{Na}$ avaliação das principais conquistas obtidas pelos empreendimentos, desde o primeiro mapeamento realizado em 2007 até o ano de 2013, conforme o Gráfico 2, percebemos que, no meio rural potiguar, as principais conquistas solidárias estão relacionadas com as conquistas para a comunidade local $(51,12 \%)$, destacando-se, juntamente com os investimentos e sobras obtidas no empreendimento, a união associativa para implementação de infraestruturas na comunidade, principalmente na construção da sede, de moradias e de escolas.

Gráfico 2. Principais conquistas dos Empreendimentos Solidários no RN (2013)

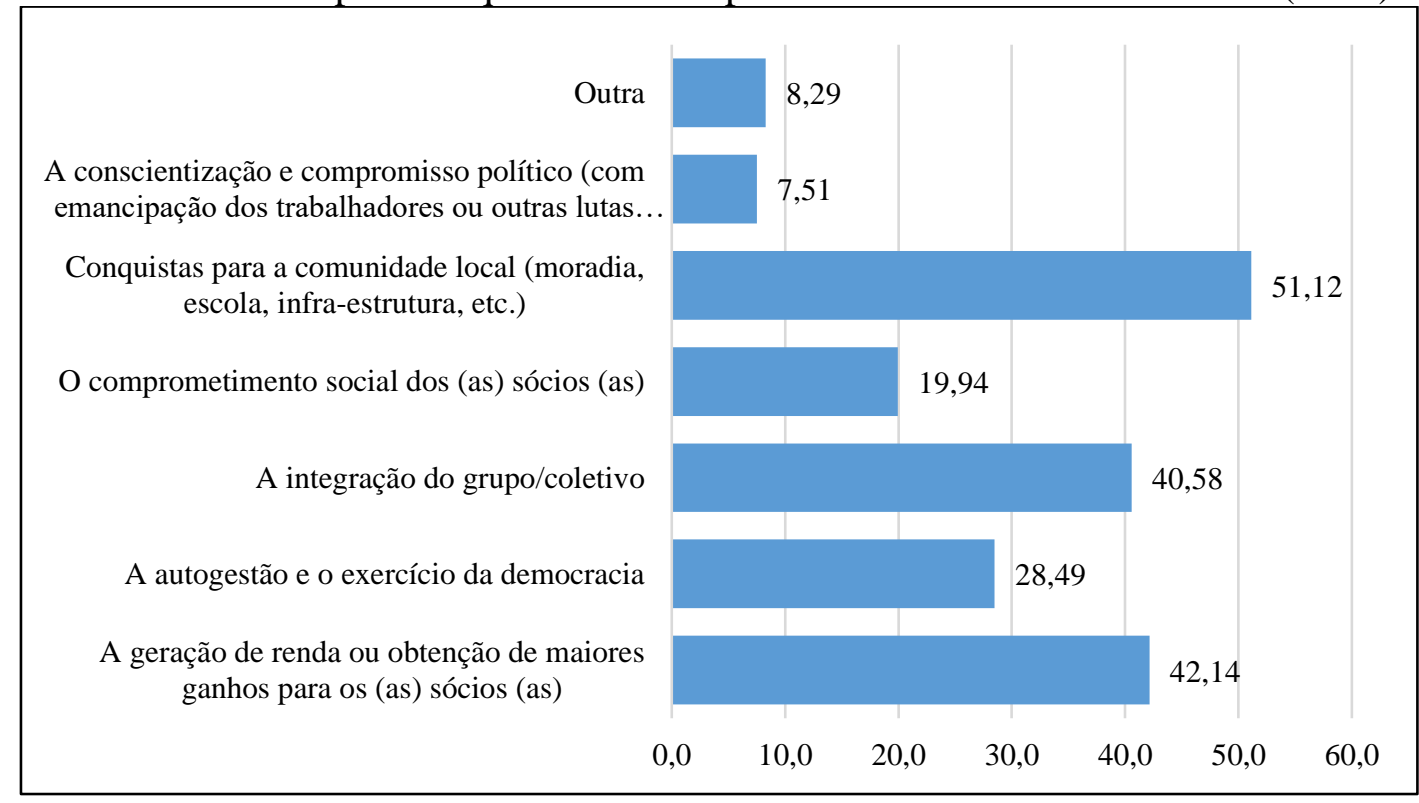

Fonte: SIES, 2013.

As demais conquistas, atreladas a geração de renda e obtenção de ganhos $(42,14 \%)$, a integração do grupo coletivo (40,58\%), o exercício da autogestão (28,49\%), além do comprometimento social $(19,94 \%)$, correspondem aos anseios dos motivos de criação dos empreendimentos solidários, demonstrando, apesar das consequências das contradições capitalistas e do Estado, que os empreendimentos, principalmente pela sua atuação política no $\mathrm{RN}$, apresentam algumas conquistas positivas, em especial, pela sua organização em rede, apesar de se caracterizarem de forma pontual, frente as dificuldades vivenciadas.

A maioria das conquistas atrela-se a realização da comercialização pelo empreendimento, contribuindo para a redução da sujeição dos trabalhadores associados diante dos agentes hegemônicos, ampliando a renda familiar e dos empreendimentos. No meio rural potiguar, a partir do Gráfico 3, pode-se observar que a maioria dos empreendimentos solidários concentram sua comercialização nas feiras livres $(50,28 \%)$, principalmente na cidade mais próxima. Essa 
prática de comercialização dos produtos nas localidades mais próximas, favorece os trabalhadores solidários indiretamente, pois contribuí para o desenvolvimento local, por meio da dinamização da economia e de acesso serviços.

Por outro lado, o Estado não vem a fomentar a criação de programas locais ou até mesmo propiciar espaços para a comercialização dos produtos. Isso reflete na dificuldade de entrega direta aos clientes, representando apenas $39,01 \%$ dos empreendimentos solidários, frente a presença dos atravessadores, expropriando a renda da terra e a mais-valia do trabalho e da produção associada nesses empreendimentos, impedindo a justa e ampla inserção dos agricultores no mercado, como no caso das feiras livres e exposições eventuais ou de Economia Solidária e agroecologia, com um universo de $17,34 \%$ e $11,17 \%$, respectivamente.

Gráfico 3. Rio Grande do Norte: espaços de comercialização solidária (2013)

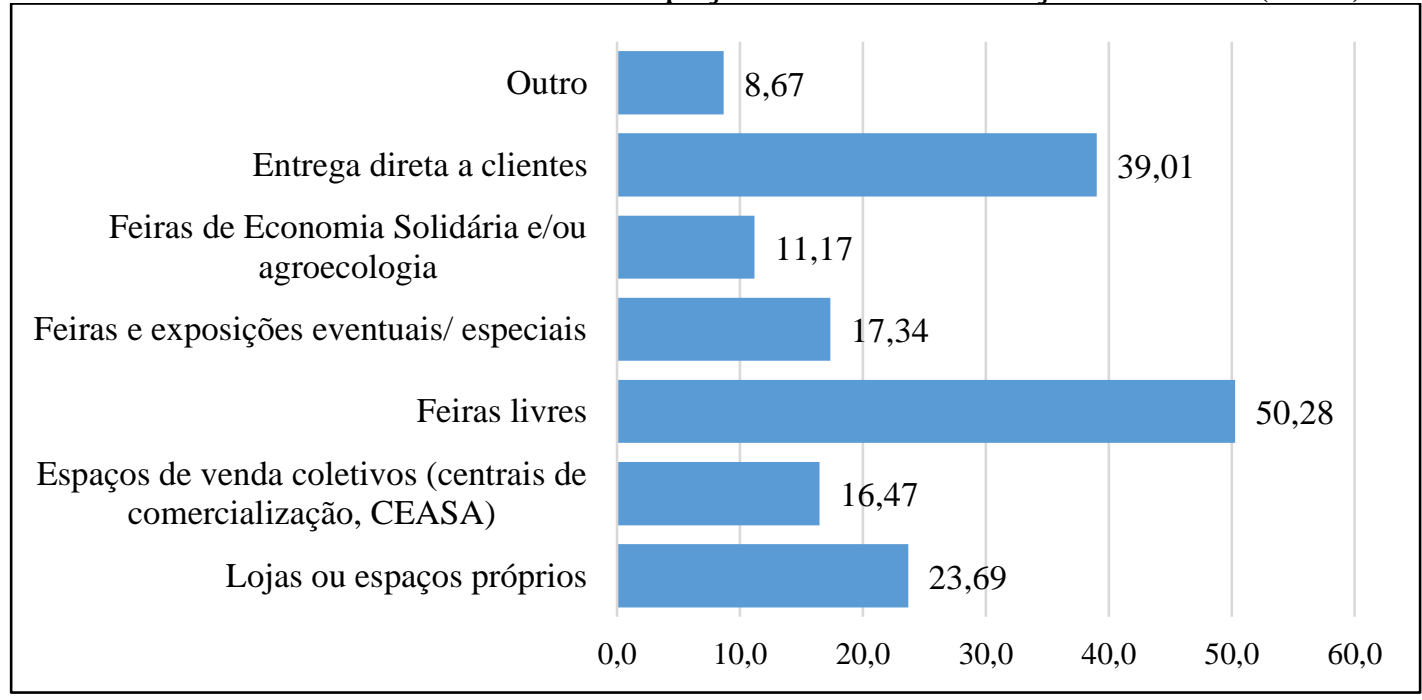

Fonte: SIES, 2013

Ainda, com base no Gráfico 3, os empreendimentos que apresentam maiores investimentos em infraestrutura produtiva e logística, comercializam sua produção em espaços de vendas coletivas $(16,47 \%)$, principalmente no CEASA da capital. Outros beneficiam a sua produção, comercializando em lojas $(23,69 \%)$, ou seja, em espaços próprios, em sua maioria localizado nas cidades para a venda dos produtos beneficiados, seja o mel, a castanha, o artesanato, inclusive os doces.

Ao analisar os dados contidos no Gráfico 4, verificamos que a venda direta ao consumidor final $(65,31 \%)$ se destaca no meio rural potiguar, principalmente pela atuação dos associados nessas feiras livres, acarretando maior autonomia e emancipação, diferentemente da venda para atacadistas $(27,74 \%)$, para órgãos governamentais $(18,20 \%)$ e para empresas 
privadas $(4,62 \%)$ que, muitas vezes, impõem os seus preços nos produtos e causam relação de dependência para os associados, também pela exigência de prazos para pagamentos e os atrasos, muitas vezes ocasionados pelas vendas institucionais, prejudicando os ganhos dos associados para investimentos na produção.

Gráfico 4. Rio Grande do Norte:

realização da comercialização do empreendimento (2013)

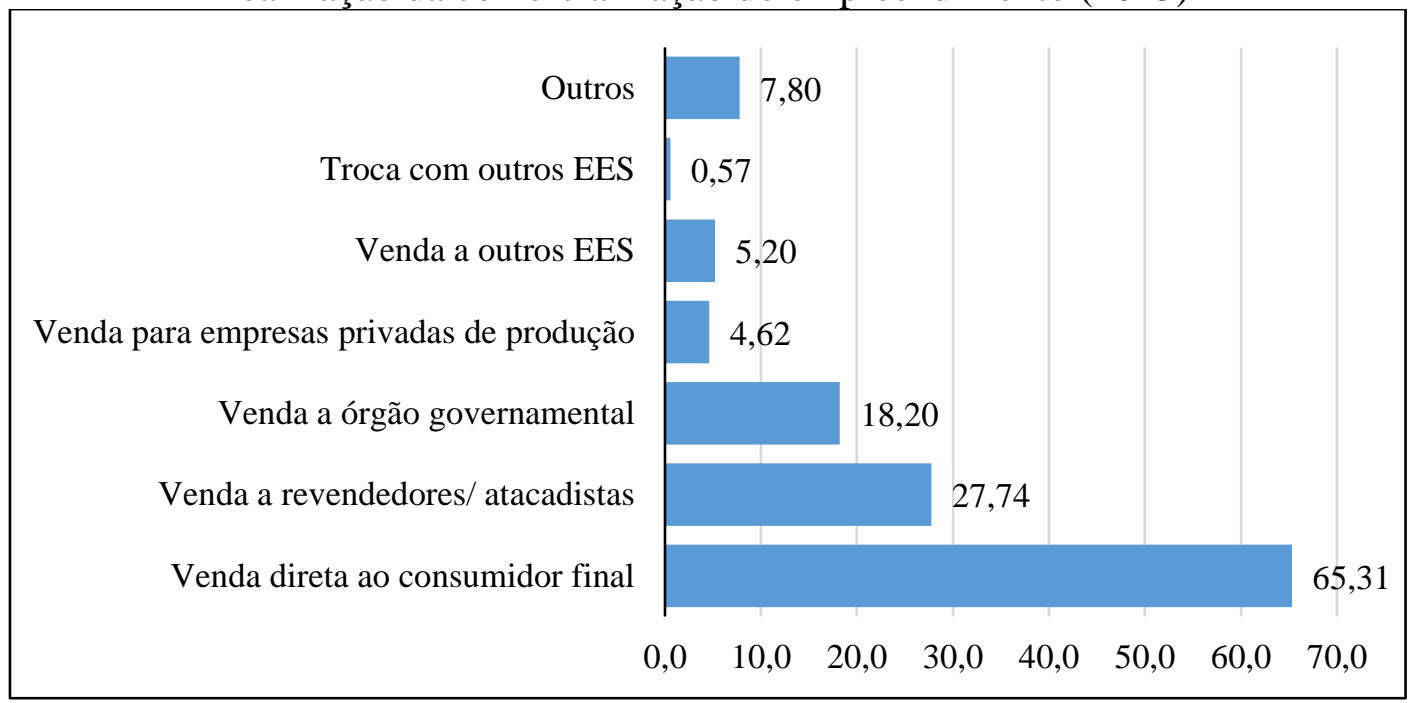

Fonte: SIES, 2013.

Todavia, em meio as visitas de campo, conseguimos desvendar algumas dificuldades na Economia Solidária potiguar quanto a comercialização, seja por não desvinculação da cultura capitalista, pela tendência a realização de tarefas individualizadas, seja pelo frágil incentivo das ações do Estado. Dessa maneira, em relação aos responsáveis pelas vendas nos empreendimentos solidário, seja na feira ou em qualquer outro espaço de comercialização, conforme demonstram os dados do Gráfico 5, fica notória a individualidade e a responsabilidade de cada associado vender o seu próprio produto, com o percentual de $45,71 \%$ destes.

Assim, o empreendimento solidário que poderia fortalecer a comercialização conjunta, apenas é utilizado para conseguir investimentos coletivos, principalmente em infraestrutura, pois grande parte das vendas se dá de forma individualizada. Porém, quando a comercialização é realizada conjuntamente, ainda prevalece o individualismo nas ações, uma vez que o agricultor só recebe o percentual da contribuição pelo valor produzido, ficando as sobras com alguns sócios responsáveis pelas vendas do EES, percentual que representa $25,71 \%$ dos associados. 
Gráfico 5. Rio Grande do Norte: responsável pelas vendas no EES (2013)

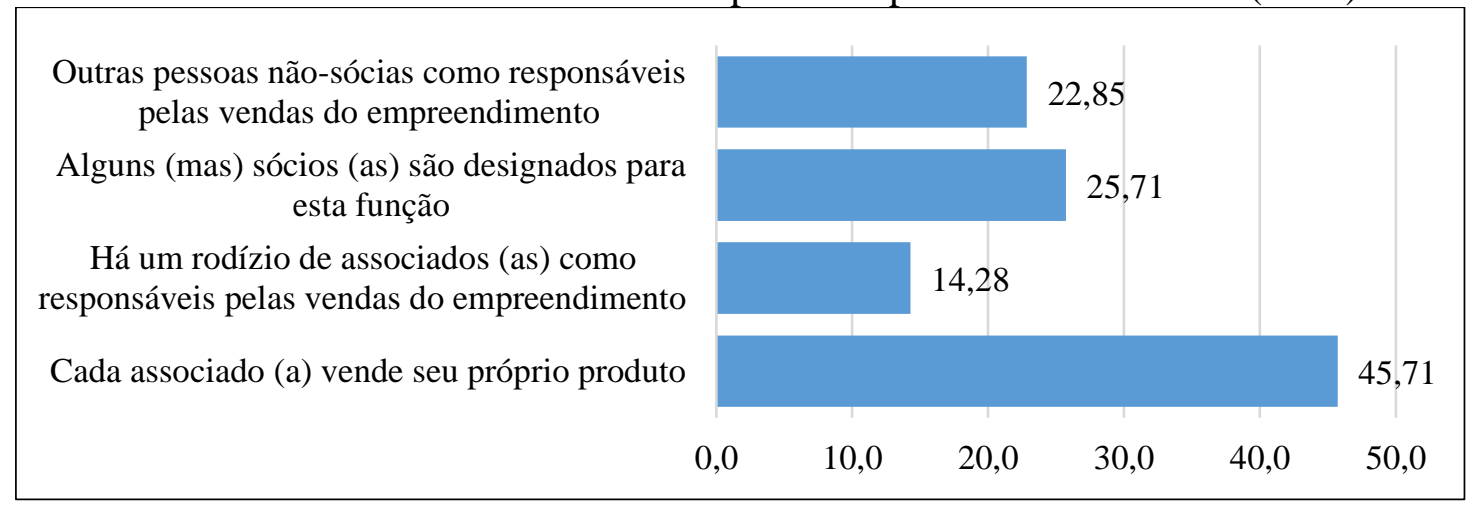

Fonte: SIES, 2013.

Casos mais alarmantes acontecem quando outras pessoas não-sócias são responsáveis pelas vendas, com 22,85\%, precarizando o circuito solidário no âmbito da comercialização, pois os associados são beneficiados apenas com a pequena parte da venda de sua produção. Deveria ocorrer o fortalecimento das ações entre os associados, até mesmo no sistema de rodízio das vendas, representando apenas $14,28 \%$, pois é a maneira mais democrática e cooperada para a realização das vendas.

Ao analisarmos essas fragilidades da Economia Solidária no meio rural potiguar, algumas dificuldades se destacam, muitas vezes reflexo não só do caráter capitalista presentes nas ações do Estado, que não contribui muito para a consolidação das iniciativas solidárias, mas pela cultura capitalista permeando as relações sociais no âmbito das iniciativas solidárias, necessitando um olhar cada vez mais analítico aos usos do território.

Com isso, ao analisarmos o Gráfico 6, percebemos que dois dos principais desafios dos empreendimentos solidários são de caráter econômico, pois 59,32\% dos associados almejam viabilizar economicamente o empreendimento e 53,10\% gerar renda adequada aos sócios. No fundo, esses principais desafios têm caráter capitalista se pensarmos a partir dos preceitos e valores da Economia Solidária. 
Gráfico 6. Rio Grande do Norte: principais desafios dos Empreendimentos Solidários ${ }^{6}$ (2013)

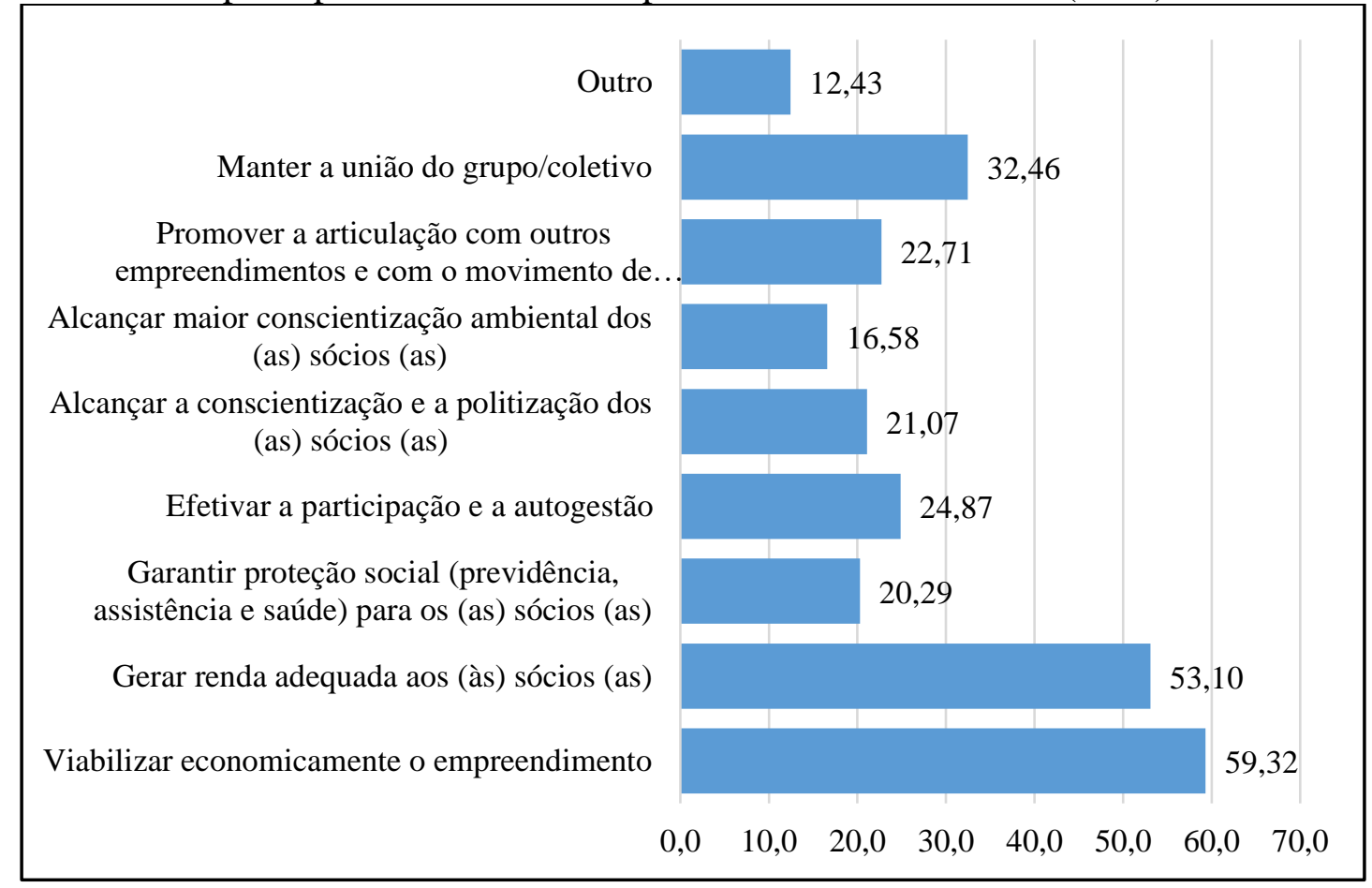

Fonte: SIES, 2013.

De acordo com Corragio (2005), na Economia Solidária, a viabilização de uma outra economia só acontece se modificarmos inicialmente nossa forma de nos relacionarmos desde a produção até a comercialização, isso indica que a viabilização econômica, seria consequência da organização solidária entre os associados. Contudo, a visão de manter a união do grupo coletivo pelas ações solidárias só aparece em terceiro lugar, com 32,46\%, seguido da efetiva participação e a autogestão, representado por $24,87 \%$, da promoção de articulação com outros empreendimentos, tendo $22,71 \%$, e do alcance da conscientização e politização dos sócios, com $21,07 \%$, bem como da conscientização ambiental e da proteção social aos associados, com $16,58 \%$ e $20,29 \%$, respectivamente.

Diante desses números, a operacionalização dos princípios solidários é secundarizada entre os associados. A visão destes no empreendimento sempre é gerar renda e trabalho, tirandoos da informalidade e da situação de marginalização social, embora suas ações muitas vezes não correspondam a realidade solidária. Isso se deve à falta de diálogo em relação aos princípios

\footnotetext{
${ }^{6}$ Os dados apresentados no gráfico não totalizam $100 \%$, pois de acordo com a metodologia da SENAES, além dos questionários conter questões abertas e fechada, as questões fechadas podiam apresentar múltiplas marcações. Diante disso, os dados representados podem ser menores ou maiores que $100 \%$.
} 
e valores solidários, na tentativa de criar boas perspectiva para o seu desenvolvimento, não só como alternativa capitalista, mas como política pública.

A dificuldade da Economia Solidária em galgar novos mercados reflete na baixa capacidade produtiva desses empreendimentos, com alguns limites na sua dependência ao mercado local. Para atender às demandas do mercado capitalista, principalmente nas vendas em atacado, se faz necessário dispor de infraestrutura técnica, de capital, mão-de-obra e várias outras condições, não dispostos nos empreendimentos de Economia Solidária, sem falar no fator tempo de produção, que em empreendimentos do agronegócio, pelo emprego de técnicas agrícolas, é menor.

Uma das formas de atuação do Estado junto a esses empreendimentos, com vistas a garantir a manutenção e viabilização econômica dos mesmos, se dá via oferta de crédito aos associados, embora com valores bem baixos e de maneira muito incipiente. Assim, ao analisar os dados representados no Gráfico 7, verificamos que $72 \%$ dos empreendimentos não buscaram acessar crédito, seja pela falta de formalização ou pelo desconhecimento dessa disponibilidade. Entretanto, dos 27,97\% dos empreendimentos que buscaram crédito, apenas 11,65\% conseguiram, enquanto que os outros $16,32 \%$ não obtiveram nenhuma forma de financiamento.

Gráfico 7. Rio Grande do Norte: acesso ao crédito pelos Empreendimentos Solidários (2013)

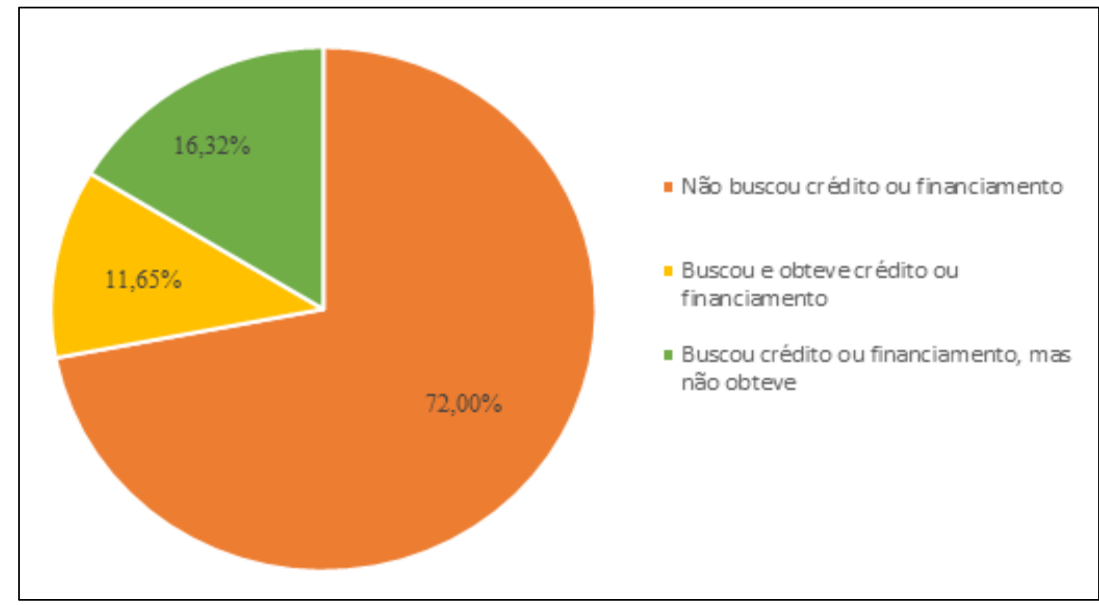

Fonte: SIES, 2013.

Diante das dificuldades em obter financiamento, houve impactos diretamente na capacidade de investimento dos empreendimentos. Os dados institucionais demonstram que $76,51 \%$ dos empreendimentos não realizaram nenhum tipo de investimento. Em termos absolutos, 880 empreendimentos solidários não realizaram investimentos, de um total de 1.158 (SIES, 2013), fragilizando o desenvolvimento da Economia Solidária no Rio Grande do Norte, 
principalmente no meio rural, menos estruturados que os empreendimentos urbanos. Dos empreendimentos que realizaram investimentos, ou seja, os $23,48 \%$ restante, a maior parte são urbanos (SIES, 2013).

Sem investimentos e organização solidária adequada, os empreendimentos econômicos têm necessidade de financiamentos, principalmente para a produção e aquisição de equipamentos e construção de infraestruturas. Dessa maneira, grande parte dos empreendimentos que não conseguiram investimento, 69,68\% dos empreendimentos do RN necessitam de algum tipo de financiamento público a fim de melhorar a infraestrutura na produção, na organização da sede ou até mesmo na comercialização. Por outro lado, 30,31\% dos empreendimentos declararam não necessitam de financiamento. Essa situação, deve-se ao fato desses empreendimentos terem sido atendidos em algum tipo de projeto ou programa antes ou no momento da pesquisa do mapeamento.

Portanto, a não necessidade de financiamento está ligado a organização e manutenção das práticas solidárias no empreendimento. Nesse universo, dos 30,31\% que não necessitam de financiamento, $12,86 \%$ investem no empreendimento utilizando o seu fundo de reserva a partir das sobras obtidas. Quando não tem nenhuma eventualidade para sanar, seja em um período de perda da produção ou de baixa comercialização, as sobras, na maioria dos empreendimentos, são utilizadas para investimentos. Somente $6,56 \%$, distribuem suas sobras aos sócios; $1,46 \%$, utilizam para assistência técnica e ações formativas e 1,81\%, para integralizar o capital, conforme a nossa pesquisa de campo.

Outros tipos de investimentos que os empreendimentos solidários dispõem relacionamse com articulações do Estado às diferentes instituições, colaborando nas práticas econômicas solidárias do RN. Dentre as instituições, destacamos: a UFRN, a UERN, a UFERSA, a EMATER, a EMPARN, o SEBRAE, dentre outros órgãos que atuam desde a implantação de projetos pedagógicos e produtivos, até a capacitação e assistência técnica e práticas de incubação. Para essas necessidades, o Estado se destaca na oferta de assistência técnica a $37,30 \%$ dos empreendimentos, dada a grande maioria dos empreendimentos rurais necessitarem de apoio técnico, conforme observamos no Gráfico 8. 
Gráfico 8. Rio Grande do Norte:

tipo de assessoria ou capacitação dada aos Empreendimentos Solidários (2013)

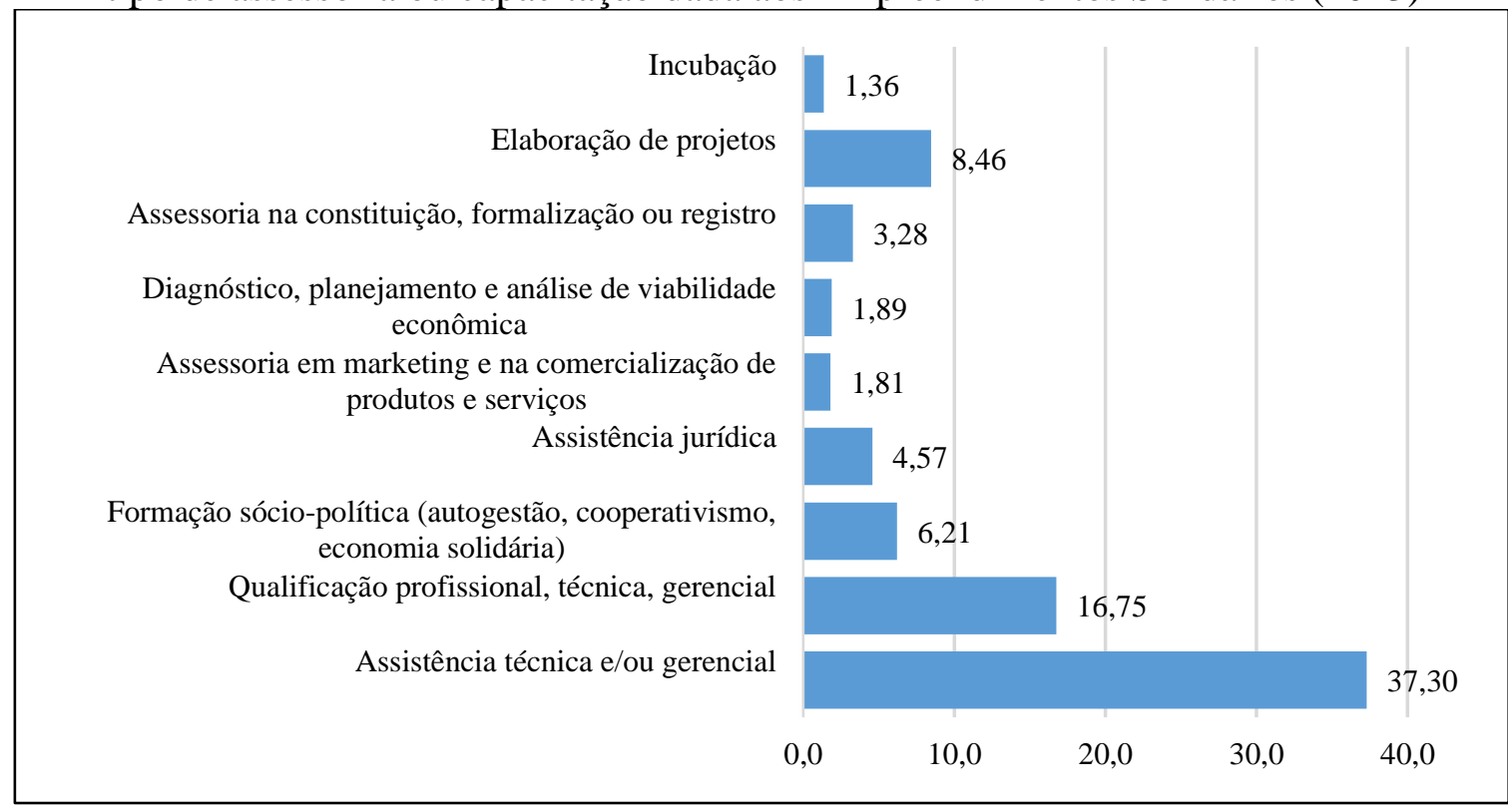

Fonte: SIES, 2013.

Em seguida, destacam-se as capacitações profissionais, técnica ou gerencial com 16,75\%, muitas vezes, propostas pelos projetos de extensão das universidades e até mesmo por suas incubadoras. Posteriormente, em menor grau, evidencia-se a elaboração de projetos, representando $8,46 \%$, a formação sociopolítica dos associados, tendo 6,21\%, como também a assistência jurídica, englobando 4,57\%, assessoria no marketing e na comercialização, com apenas $1,81 \%$, e diagnósticos de viabilidade econômica com $1,89 \%$, dos quais nessas três últimas assessorias os empreendimentos buscam a formalização, principalmente junto ao SEBRAE ${ }^{7}$.

A participação dos sócios nas decisões cotidianas dos empreendimentos, é um dos princípios essenciais da Economia Solidária: a autogestão. Sendo assim, a expressiva maioria dos empreendimentos, com $92,14 \%$, realiza a autogestão por meio de assembleias ou reuniões coletivas entre os sócios. São nas assembleias que se define e socializam a realidade da produção do empreendimento, as atividades realizadas e os destinos das sobras, qual a

\footnotetext{
${ }^{7}$ No Rio Grande do Norte, destaca-se o SEBRAE, distanciando-se dos princípios e valores de Economia Solidária, pois parte do princípio do empreendedorismo individual, no qual cada um deve galgar seu espaço no mercado, gerando assim competitividade e buscando lucro. O SEBRAE oferece o caminho para a formalização dos empreendimentos, viabilizando o acesso a créditos bancários e realização de investimentos, porém de forma mercantil. Até mesmo a capacitação dada pelo SEBRAE é na perspectiva mercadológica, alienando mais ainda os camponeses, na maioria à margem do processo.
} 
porcentagem a ser rateada e a porcentagem destinada ao fundo de reserva, a contribuição de cada associado, dentre outras pautas.

Em relação a periodicidades dessas assembleias, em 49,13\% dos empreendimentos, são mensais; no restante, ocorre de forma bimestral ou trimestral, 23,31\%; semestral, 10,44\%; anual, 9,06\%; e diariamente, 1,38\%, diante da nossa pesquisa de campo. Diante desse contexto, as assembleias são a forma mais democrática de autogestão nos empreendimentos do RN, uma vez que depois delas, a instância de participação dos sócios se restringe a Coordenação/Diretoria, realidade encontrada em 51,20\%, ou ao Conselho Fiscal, com 41,70\%, no qual se aplica aos empreendimentos mais estruturados em termos de organização solidária.

Em menor grau, conforme se observa no Gráfico 9, a participação restringe-se ao Conselho Administrativo, tendo 9,49\% dos empreendimentos, ao Grupos de Trabalhos ou Instâncias de Direção, com 6,47\%, e ao Conselho Consultivo ou Conselho de Ética, com 2,93\% e 2,67\%, respectivamente. Em muitos destes conselhos, há imposição nas escolhas dos associados, pois votam nas alternativas sugeridas, em detrimento de construírem conjuntamente soluções para os seus problemas ou para a destinação dos investimentos, das sobras e de outras instâncias do empreendimento.

Gráfico 9. Rio Grande do Norte:

instância de participação dos sócios do empreendimento ${ }^{8}$ (2013)

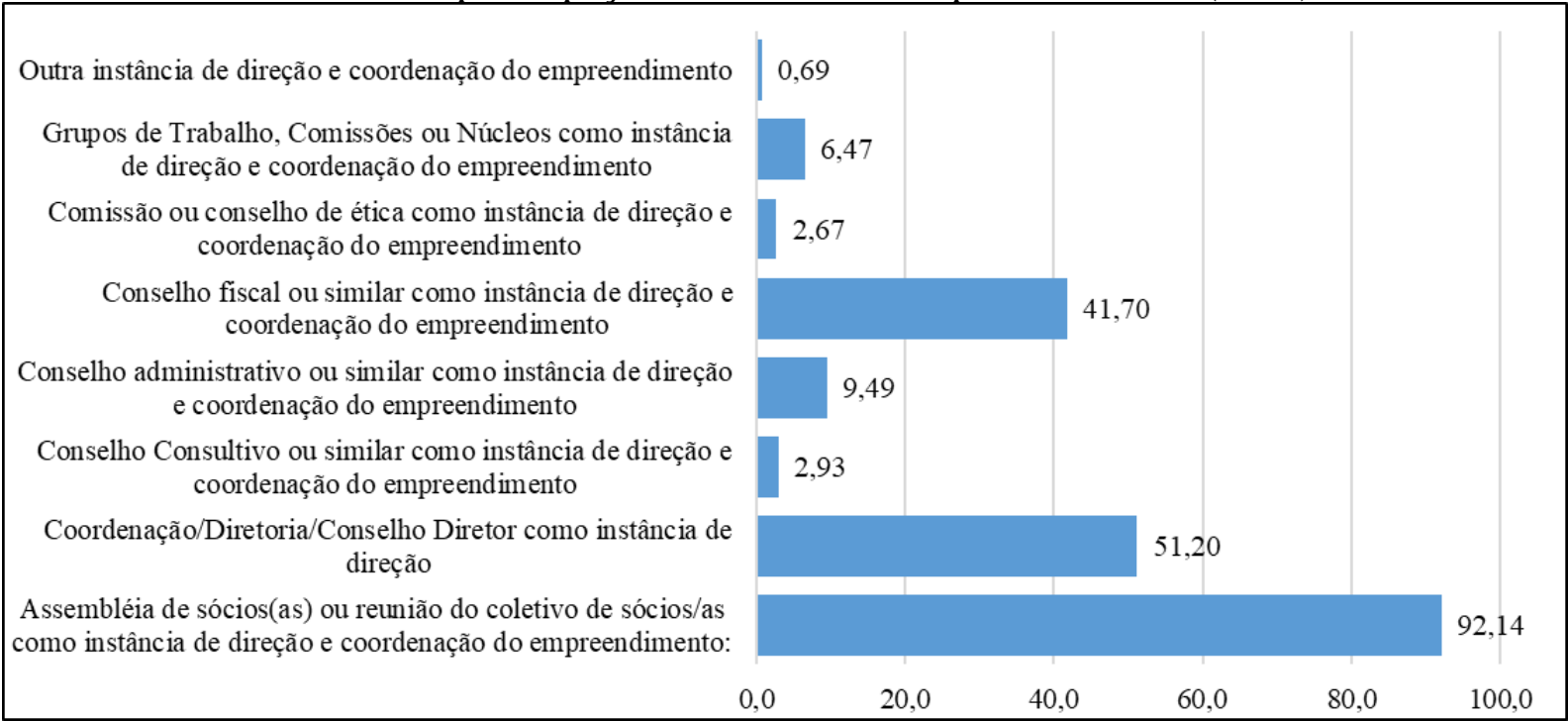

Fonte: SIES, 2013

\footnotetext{
${ }^{8}$ Os dados apresentados no gráfico não totalizam $100 \%$, pois de acordo com a metodologia da SENAES, além dos questionários conter questões abertas e fechada, as questões fechadas podiam apresentar múltiplas marcações. Diante disso, os dados representados podem ser menores ou maiores que $100 \%$.
} 
Nesses conselhos, constituídos nos empreendimentos, pelo seu caráter jurídico, social, econômico e muitas vezes técnico, 96,28\% dos participantes recebem remuneração ou alguma gratificação pela função administrativa desempenhada. Isso reflete diretamente nos resultados das atividades e nos custos desembolsados pelos empreendimentos, pois ao analisarmos a dimensão dos recursos, vemos que $36,96 \%$ dos empreendimentos potiguares pagam as despesas e não apresentam nenhuma sobra, apenas $27,54 \%$ pagam as despesas e obtém alguma sobra. Deste último universo, 19,82\% têm como instância de participação do sócio as assembleias, sendo a forma de participação menos significativa entre os sócios dos empreendimentos (SIES, 2013).

Diante desse conjunto de dados, buscamos demonstrar os nexos encontrados entre o contexto institucional da Economia Solidária, a partir dos dados secundários, e a realidade empiricamente observada em nossas atividades de campo. A análise dos dados é reveladora das fragilidades da Economia Solidária potiguar, pois as desigualdades vividas pelos associados aos empreendimentos são perceptíveis.

Sendo assim, constatamos que as necessidades desses agricultores solidários é garantir sua reprodução social dignamente, todavia a reprodução ampliada do capital, base da atuação dos principais agentes sociais, representado consubstancialmente pelo mercado e pelo Estado, condiciona formas de reprodução capitalista que permeiam fortemente as relações sociais desses agricultores.

Diante dessa vulnerabilidade, frente as ações do mercado e do Estado, verificamos que a ênfase no momento da produção e da comercialização seja a condição primaz para garantir a reprodução dos trabalhadores associados aos empreendimentos solidários. Entretanto, vivenciamos no meio rural potiguar uma fase preocupante no fomento a Economia Solidária a partir da organização desses empreendimentos em redes, constituindo alguns circuitos espaciais produtivos solidários, a fim de obter condições mais justas de produção e comercialização. No contexto norte-rio-grandense, $59,41 \%$ dos empreendimentos participam de rede ou fórum de articulação, e 40,58\% que não participam (SIES, 2013).

O grau de participação desses empreendimentos em rede ainda é pouco e o número das redes solidárias também o é, apenas pouco mais da metade participam e constituem a única rede existente no RN, conhecida como Rede Xique-xique. Para Corragio (2004) e Singer (2002), a formação solidária em rede pode ser o ponto de partida para o fortalecimento de uma outra dinâmica econômica, talvez o início de uma globalização contra-hegemônica (SANTOS, 2004). No entanto, na realidade potiguar, apenas 38,08\% dos empreendimentos solidários associam- 
se em rede, articulam-se com os movimentos sociais, sindicais e nos fóruns de Economia Solidária, o restante, compondo $61,91 \%$, não aprimora suas relações solidárias por meio dessas articulações (SIES, 2013).

Portanto, para além dos dados institucionais, é necessário o entendimento mais amplo e profundo das relações sociais no contexto da Economia Solidária potiguar. As propostas implementadas pelas políticas sociais, por parte do Estado, são muitas vezes concebidas sem as devidas vinculações dos condicionantes econômicos e sociais da realidade que a política poderá abarcar. Em relação a Política de Economia Solidária, esses condicionantes pouco foram levados em consideração, principalmente, em se tratando de política que tenta estabelecer outra lógica de produção na realidade dominante.

Somada essas contradições, acrescenta-se a dimensão ambiental, pois na realidade do RN não é levada em consideração. Verificamos principalmente, na realidade dos assentamentos rurais, a utilização de adubos e fertilizantes químicos e rações balanceadas, com vista a potencializar a produção. As práticas agroecológicas tangência os projetos executados junto aos empreendimentos solidários, não alertando os assentados para a produção sustentável, a partir de sistemas produtivos consorciados. Porém, muitas vezes, a implantação desses sistemas, foge à capacidade técnica e financeira dos assentados.

Não obstante, alguns empreendimentos que souberam aproveitar as potencialidades locais, partindo da organização social em rede, embora de ordem regional, conseguiram suscitar desenvolvimento econômico e redução da situação de vulnerabilidade social dos assentados, com inovações nas formas de produção e organização do trabalho, apesar de não se livrarem do processo de concorrência capitalista e das ações de tutelamento por parte do Estado, acrescentado de produção individual, em detrimento da coletiva.

\section{CONSIDERAÇÕES FINAIS}

As constatações até então concebidas, permite-nos evidenciarmos as fragilidades do arranjo institucional da Política de Economia Solidária potiguar, frente a ações na dinâmica territorial do meio rural. Como estratégias de reprodução social, esta deveria permitir o desenvolvimento socioeconômico, fortalecendo a geração de trabalho e renda nas áreas rurais do RN, como um instrumento de emancipação e integração dos seus empreendimentos pelo território. No entanto, esta vem se realizando pela necessidade de maiores ganhos financeiros, 
a fim de complementar a renda familiar ou dos colaboradores que comanda os empreendimentos.

Para tanto, com a perspectiva financeira evidenciada aos poucos os empreendimentos solidários vão se tornando funcional ao capital, perdendo sua característica revolucionária, da luta por um processo de mudanças, incorporando de fato um processo de contenção das desigualdades e contradições no campo. A baixa remuneração e de ganhos econômicos ainda permeia todos os empreendimentos solidários, o que representa a manutenção das condições precárias nas relações de trabalho, sem falar que a figura do atravessador, ainda permanece nessa "renovada" forma de produção da Economia Solidária.

Chamamos atenção para a palavra renovada, porque muitos dos assentados desconhecem os princípios e valores da Economia Solidária; nem ao menos sabem que foram autodenominados assim ou que estão inseridos no cadastro da SENAES como um empreendimento econômico solidário. Nas áreas visitadas, ainda permanece mesmo a denominação Cooperativa ou Associação, certas denominações da Economia Solidária ainda não foram absorvidas, o que demonstra que empiricamente os "novos" princípios solidários ressaltados, ainda precisam ser construídos conjuntamente e socialmente, a partir de formações pedagógicas que devem inserir esses princípios desde o processo de implementação do empreendimento.

Como uma alternativa a produção capitalista, os empreendimentos de economia solidária não vêm se consolidando como um movimento emancipatório, de forma contraditória estes dependem fortemente das políticas e decisões econômicas do Estado e demais instituições, o que dificulta as ações dos empreendimentos desde a produção, pela dependência de projetos e parcerias produtivas, até a comercialização, pelos mercados institucionais, onde muitas vezes os preços são ditados sobre regras estritamente capitalistas. Ainda com a atuação do Estado, a Economia Solidária também perdeu sua configuração como um movimento político e social, que luta pelo direito à cidadania, por melhores condições de trabalho e superação das desigualdades. $\mathrm{Na}$ realidade nacional, $88 \%$ dos empreendimentos ainda carecem de formalização adequada, $61 \%$ de comercialização adequada, $58 \%$ de acesso ao crédito e $62 \%$ de acesso ao conhecimento (SIES, 2013).

Dessa maneira, a Economia Solidária no Rio Grande do Norte, descreve um caminho complexo e contraditório, por não ter a capacidade de reafirma uma nova organização produtiva, sobretudo, que seja alternativa ao modelo econômico vigente. Esta se torna complementar as desigualdades capitalistas, criando e mantendo novos mecanismos de 
equilíbrio e controle das massas para a reprodução ampliada do capital. Em relação a realidade rural, nesta se mantém grande parte dos associados de empreendimentos solidários marginalizados, apartados do processo de modernização do campo, em condições produtivas desiguais, principalmente quanto a sua inserção no mercado.

Assim, a Economia Solidária, incentivada pelo estado, embora se constitua em um modelo alternativo de organização socioeconômica, minimizando o contexto de subordinação a que estes trabalhadores rurais estão submetidos e ampliando suas relações sociais de produção, as ações institucionais que fragilizam a participação plena dos associados, apenas complexificou as relações e trouxe novos mecanismos de subordinação, mantendo esses sujeitos sociais subjugados indiretamente aos ditames assistencialistas do Estado, dos interesses dos capitais e dos grandes proprietários rurais locais.

\section{REFERÊNCIAS}

CORAGGIO, José L. Da economia dos setores populares à economia do trabalho. In.: KRAYCHETE, Gabriel et al (Org). Economia dos setores populares: entre a utopia e a realidade. Rio de Janeiro: Vozes, 2004.

LOCATEL, Celso Donizete; LIMA, Leandro de Castro. Do cooperativismo à economia solidária no Brasil: normatização e dinâmica econômica no campo. In: ZAAR, Miriam; CAPEL, Horacio. (Org.). Las Ciencias Sociales y la Edificación de una Sociedad PostCapitalista. 1ed.Barcelona: Universidad de Barcelona/Geocrítica, 2018, v. 1, p. 1-22. Disponível em: <http://www.ub.edu/geocrit/Sociedad-postcapitalista/Indice.pdf> ou <http://www.ub.edu/geocrit/Sociedad-postcapitalista/LocatelLima.pdf >. Acesso em: 20 de fev. 2021.

RIO GRANDE DO NORTE. Decreto $\mathrm{N}^{\circ}$ 30.371, de 02 de fevereiro de 2021. Dispões sobre o Programa Estadual de Crédito da Economia Solidária. DOE N 14.835. p. 1. 2021.

SANTOS, Milton. A natureza do espaço: técnica e tempo. Razão e emoção. São Paulo: Edusp, 2000.

SANTOS, Milton. Por uma outra globalização: do pensamento único à consciência universal. $11^{\text {a }}$ Ed. Rio de Janeiro: 2004.

SANTOS, Milton; SILVEIRA, María Laura. O Brasil: território e sociedade no início do século XXI. 10a ed. Rio de Janeiro: Record, 2008.

SECRETÁRIA NACIONAL DE ECONOMIA SOLIDÁRIA - SENAES: 2013. Brasília. Disponível em: www.mte.gov.br. Acesso em: 20 Jan. 2014.

SENAES/MTE. Economia Solidária como estratégia e política de desenvolvimento. I Conferência Nacional de Economia Solidária, Documento Final, 2013. 
SINGER, Paul. Introdução à economia solidária. $1^{\text {a }}$ edição, São Paulo: Editora Fundação Perseu Abramo, 2002.

SISTEMA NACIONAL DE INFORMAÇÕES EM ECONOMIA SOLIDÁRIA (SIES) SENAES: 2013. Brasília. Disponível em: sies.ecosol.org.br/atlas. Acesso em: 28 Jan. 2015.

SISTEMA NACIONAL DE INFORMAÇÕES EM ECONOMIA SOLIDÁRIA (SIES) SENAES: 2013. Brasília. Disponível em: sies.ecosol.org.br/atlas. Acesso em: 28 Jan. 2015.

Recebido em 30 de setembro de 2021

Aprovado em 18 de dezembro de 2021

Publicado em 07 de fevereiro de 2022 